\title{
CLOVER ROOT WEEVIL: OBSERVATIONS ON DIFFERENCES BETWEEN 1997 AND 1998 SUMMER POPULATIONS IN THE WAIKATO
}

\author{
P.J. ADDISON, B.E. WILLOUGHBY, S. HARDWICK \\ and P.J. GERARD
}

AgResearch, Private Bag 3123, Hamilton

\begin{abstract}
Field population studies of clover root weevil in the Waikato in 1996/97 showed that high levels of reproductive females in early summer were followed by a summer larval generation. However, in the 1997/98 summer, non-reproductive females predominated and a summer generation of larvae did not eventuate. Rainfall during the 1997/98 summer was less than in the preceding summer. The possibility that dry conditions inhibited the initiation of oviposition is supported by experimental evidence showing that females collected from irrigated pastures laid almost 100 times more eggs over a one month period than those from non-irrigated pastures.
\end{abstract}

Keywords: Sitona lepidus, reproduction, population, irrigation.

\section{INTRODUCTION}

The clover root weevil (Sitona lepidus Gyllenhal (Coleoptera: Curculionidae)), a potentially serious clover pest, was first recorded in New Zealand in 1996 (Barratt et al. 1996). Subsequent examination of stored weevil samples revealed that it had been present in the Waikato in 1995 (Barker et al. 1996). Surveys conducted in 1996 and 1997 revealed that $S$. lepidus was present and spreading throughout large areas of Northland, the Waikato and coastal Bay of Plenty (Barker et al. 1996; Willoughby and Addison 1997a). Currently (April 1998), S. lepidus has been reported as far north as Whangerei, south to near Te Kuiti and south east into the Rotorua/Reporoa district (Addison, unpubl. data).

Population studies in the Waikato in 1996 and 1997 indicated that S. lepidus can complete two generations per year (Willoughby and Addison 1997b). This paper reports on the marked differences between S. lepidus populations in the 1996/97 and $1997 / 98$ summers and early investigations into contributing factors.

\section{Monitoring of field populations}

\section{MATERIALS AND METHODS}

Thirty soil cores (10 cm diameter x $10-15 \mathrm{~cm}$ deep) were taken randomly along a $50 \mathrm{~m}$ transect at approximately three weekly intervals at two sites (Hamilton and Springdale, both in the Waikato region). S. lepidus adults and larvae were extracted from the cores by wet sieving and flotation in $\mathrm{MgSO}_{4}$ solution. At each sampling date, 50 adults were collected from pasture using a suction apparatus (modified Homelite HB180V blower/vac.) and the reproductive development of female weevils was assessed (Willoughby and Addison 1997). Generalised linear model analysis was used to compare data from each summer.

Comparison of adult fecundity from irrigated and non-irrigated pastures

Adults were collected using the suction apparatus from two irrigated and two nonirrigated pastures at Ruakura Research Centre in January 1998. Ten replicates of five weevils from each of the four pastures were placed into aerated $120 \mathrm{ml}$ containers and placed in a randomised block design in a controlled environment room at $18^{\circ} \mathrm{C}$ with a $16 \mathrm{~h}$ light: $8 \mathrm{hr}$ photoperiod. Every $48 \mathrm{~h}$, eggs were removed and counted, and fresh water and white clover provided. After 31 days, weevils were dissected to confirm sex.

Proc. 51st N.Z. Plant Protection Conf. 1998: 1-4 


\section{Comparison of larval numbers in irrigated and non-irrigated pastures}

Four pairs of irrigated and non-irrigated paddocks of similar history were sampled at Bay Farms, Manawaru on March 11 1998. The irrigated pastures each received 28 $\mathrm{mm}$ of water at 6 day intervals over the course of the year. Forty soil cores $(7.5 \mathrm{~cm}$ diameter $\mathrm{x} 10 \mathrm{~cm}$ deep) were taken at random from each paddock and hand sorted in the laboratory for larvae, pupae and adults.

\section{Effect of soil moisture on egg hatch and first instar survival}

Horotiu silt loam soil was sieved, oven dried for $48 \mathrm{~h}$, weighed into airtight containers and water added to achieve soil moisture contents of 5, 7.5, 10, 12.5, 15, 20 and $25 \%$ by weight. The containers were sealed and shaken daily to ensure even distribution of moisture. After one week, $20 \mathrm{ml}$ airtight plastic centrifuge vials were filled with the soils. Ten newly laid eggs (4 replicates) or 5 first instar larvae (5 replicates) were placed in each, the vials sealed and held at $25^{\circ} \mathrm{C}$. Larval survival was assessed at $24 \mathrm{~h}$ and egg hatch at 14 days.

\section{RESULTS}

Larval populations at the two sites monitored over two successive summers showed that there was a significantly larger summer generation of larvae in 1996/97 compared to $1997 / 98$ (P<0.001)(Figure 1). There was no clear relationship with larval and adult density. Adult populations at the Hamilton site were $63 / \mathrm{m}^{2}$ (SE unavailable) and $102 \pm 24 / \mathrm{m}^{2}$ in late December of 1996 and 1997 respectively. Populations at the Springdale site at the same period were $128 \pm 21 / \mathrm{m}^{2}$ and $34 \pm 14 / \mathrm{m}^{2}$. Dissection of the female weevils revealed that during December to the end of February in both 1996/97 and 1997/98, all mature female weevils had fully developed ovarioles containing developing oocytes. However, a significantly higher percentage of female weevils had eggs in the calyces over this period in 1996/97 (97 \pm 1.3$)$ than in $1997 / 98(67 \pm 4.4$, $\mathrm{P}<0.001)$ (Figure 2).

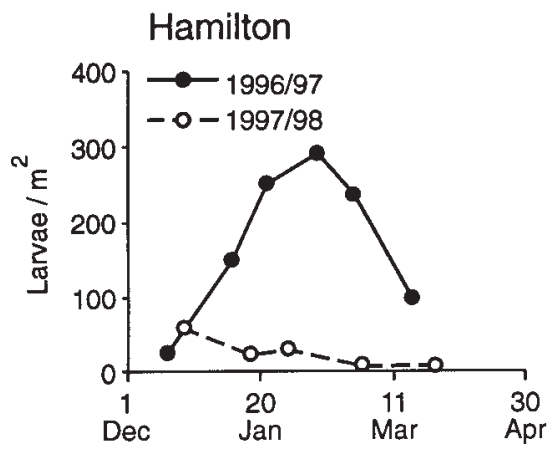

\section{Springdale}

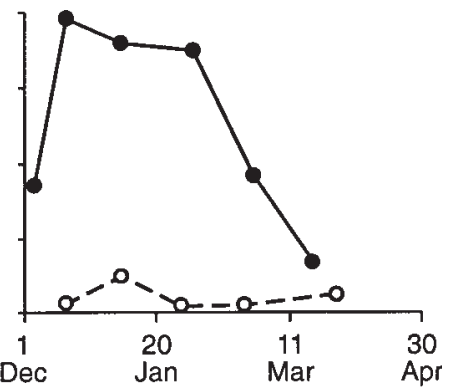

\section{FIGURE 1: Comparison of summer S. lepidus larval populations in 1996/97 and $1997 / 98$ at two Waikato sites.}

Adult female weevils collected from irrigated pastures in January 1998 laid significantly $(\mathrm{P}<0.01)$ more eggs $(3.77 /$ female/day) than those from non-irrigated pasture $(0.04 /$ female/day) over the same period.

Larval numbers were very low at Bay Farms in March 1998, and although 5 times more larvae were found in irrigated compared to non-irrigated paddocks ( 34 versus $7 / \mathrm{m}^{2}$, s.e.d. $\left.=15\right)$, the difference was not statistically significant.

Egg hatch was significantly $(\mathrm{P}<0.01)$ lower at a soil moisture of $5 \%$ than at all higher soil moisture contents (Table 1). At 25\%, egg hatch was significantly lower than at $10,12.5$ and $20 \%(\mathrm{P}<0.05)$. No first instar larvae survived $24 \mathrm{~h}$ at $5 \%$ soil moisture and survival was impaired at $7.5 \%$. 

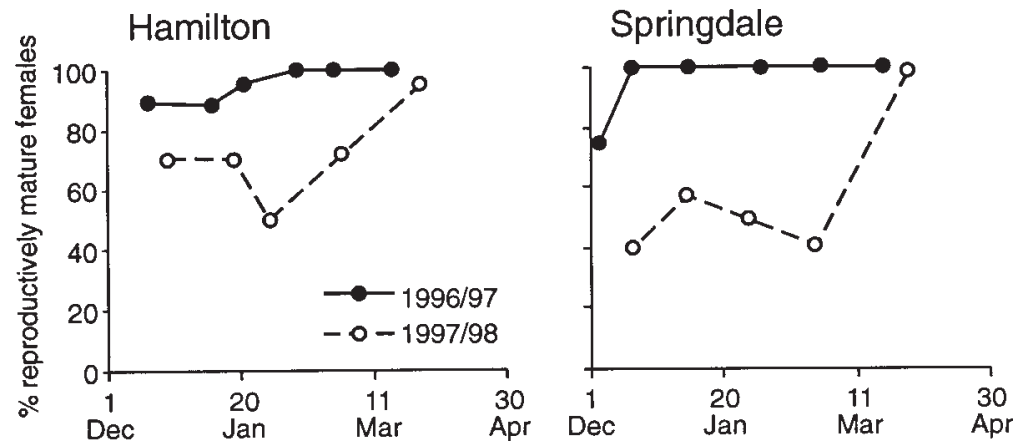

FIGURE 2: Percentage of reproductively mature females in 1996/97 and 1997/98 at two Waikato sites.

TABLE 1: Egg hatch (\%) and first instar survival (\%) at a range of soil moistures $\left(25^{\circ} \mathrm{C}\right)$.

\begin{tabular}{ccc}
\hline $\begin{array}{c}\text { \% soil } \\
\text { moisture }\end{array}$ & $\begin{array}{c}\text { Egg hatch } \\
(14 \text { days })\end{array}$ & $\begin{array}{c}\text { Larval survival } \\
(1 \text { day })\end{array}$ \\
\hline 5 & 34 & 0 \\
7.5 & 79 & 60 \\
10 & 82 & 80 \\
12.5 & 81 & 88 \\
15 & 79 & 88 \\
20 & 90 & 88 \\
25 & 63 & $42(5 \%)$ \\
\hline
\end{tabular}

\section{DISCUSSION}

While a single generation per year is typical for most Sitona (Moulden 1973), S. cylindicollis has both a spring and autumn generation under irrigation in Uzbekistan (Alimdzhanov 1941) and S. lepidus has two periods of oviposition in Northern Ireland (Mowat and Clawson 1996). Many factors may have contributed to the greatly reduced larval populations observed in the Waikato in the 1997/98 summer compared to the first summer for which data is available. Reduced numbers and/or fecundity of female weevils, scarcity of a suitable food source or adverse climatic conditions at a critical developmental stage may have played a role. Early summer adult density does not appear to be closely related to summer larval density. There is a possibility that the adult weevils emigrated from pastures to a more favourable habitat or aestivation sites as conditions became dry. This is a well documented behavioural response in other Curculionidae species (e.g. Goldson and French 1983). Clover content (5 - 20\% of total DM) in early summer was not unusually low and is unlikely to have been a primary limiting factor. The influence of adverse climatic conditions on reproductive activity is strongly implicated. Assuming a sex ratio of $1: 1$ and a potential fecundity of 400 - 3000 eggs per female (Brudea 1979), the adult population present at both sites in the spring was capable of producing a large summer larval generation. Adult emergence in 1997 (early November) was three weeks later than in 1996 (mid October) (Addison and Willoughby unpubl. data). This delay, coupled with warmer and drier conditions from December through to mid January in 1997/98 compared to 
1996/97 (mean max temp 0.6 $\mathrm{C}$ higher, rainfall $52.2 \mathrm{~mm}$ less; Ruakura Met. Stn. data), may have led to the observed incomplete reproductive maturation by females in 1997/98. This contention is supported by the large contrast in numbers of eggs laid by females collected from irrigated and non-irrigated paddocks.

The 90-fold difference in oviposition by females between irrigated and nonirrigated paddocks was not reflected in a corresponding difference in larval numbers in paddocks at Bay farms, perhaps because numbers of larvae were very low. One possibility is that the prevailing dry conditions may have inhibited hatch or caused high mortality amongst eggs and newly hatched larvae on the soil surface between times of irrigation. The results of the soil moisture experiments do not support this hypothesis as only at levels of $5 \%$ was survival greatly affected. However, the closed containers used in the assay would have created more humid conditions than found in the field. High $\left(50+{ }^{\circ} \mathrm{C}\right)$ soil surface temperatures can occur during dry summers in the Waikato (Barker and Addison unpubl. data), and could also contribute to mortality.

From the evidence presented it would appear that a drought-induced reduction in oviposition may be responsible for the differences in S. lepidus larval numbers observed in the Waikato region over the summers of 1996/97 and 1997/98. If adult migration and aestivation is occurring, an influx of adults could be evident in pasture sampling following the return of favourable conditions.

\section{ACKNOWLEDGEMENTS}

Catherine Cameron for meteorological data and statistical analyses; Meredith Thorpe, Fiona Kettlewell and Tina Eden for technical assistance.

\section{REFERENCES}

Alimdzhanov, R., 1941. The biology of the nodule weevils under conditions of irrigated lucerne. Izv. uzbek. Fil. Akad. Nauk. SSSR 1941 4: 64-70. (as cited by Moulden 1973).

Barker, G.M., Addison, P.J., Firth, A.C. and Barratt, B.I.P., 1996. Sitona lepidus Gyllenhal (Coleoptera: Curculionidae) newly established in New Zealand: assessment of distribution in the North Island. Proc. 49th N.Z. Plant Prot. Conf.: 266-269.

Barratt, B.I.P., Barker, G.M. and Addison, P.J., 1996. Sitona lepidus Gyllenhal (Coleoptera: Curculionidae), a potential clover pest new to New Zealand. N.Z. Entomol. 19: 23-30.

Brudea, V., 1979. Observations on the oviposition of the clover weevil Sitona flavescens Marsh. in the conditions of northern Moldavia. Probl. Prot. Plant. 7: 77-85.

Goldson, S.L. and French, R.A., 1983. Age related susceptibility of lucerne stands in North Canterbury, New Zealand to sitona weevil, Sitona discoideus Gyllenhal (Coleoptera: Curculionidae), larvae and the associated patterns of adult infestation. N.Z. J. Ag. Res. 26: 251-255.

Moulden, J., 1973. The biology of Sitona species with particular reference to S. humeralis. Department of Agriculture, South Australia, Agronomy Branch Report 44: $51 \mathrm{pp.}$

Mowat, D.J. and Clawson, S., 1996. Oviposition and hatching of the clover weevil Sitona lepidus Gyll. (Coleoptera: Curculionidae). Grass Forage Sci. 51: 418-423.

Willoughby, B. and Addison, P.J., 1997a. Assessment of the dispersal of Sitona lepidus (clover root weevil), in the North Island of New Zealand. Proc. 50th N.Z. Plant Prot. Conf: :33-36.

Willoughby, B. and Addison, P.J., 1997b. Clover root weevil (Sitona lepidus) - a threat to the sustainability of white clover in New Zealand pastoral systems? Pp 26-30. In: Soil Invertebrates in 1997. Allsopp, P.G., Rogers, D.J., and Robertson, L.N., (Eds): Bureau of Sugar Experimental Stations. 